\title{
A key to the freshwater triclads (Platyhelminthes, Tricladida) of Herzegovina watercourses
}

\section{LEJLA KNEZOVIĆ ${ }^{1}$ \\ MARKO MILIŠA² \\ MIRJANA KALAFATIĆ 2 \\ NIVES RAJEVIĆ2 \\ ADRIANA PLANINIĆ 1 \\ ${ }^{1}$ Faculty of Science and Education University of Mostar, Matice hrvatske bb BiH-88000 Mostar \\ ${ }^{2}$ Faculty of Science, University of Zagreb Rooseveltov trg 6, RH-10000 Zagreb \\ Correspondence: \\ Lejla Knezović \\ Faculty of Science and Education \\ University of Mostar, Matice hrvatske bb \\ BiH-88000 Mostar \\ e-mail: lejla.knezovic@fpmoz.ba}

Key words: planarians, free-living triclads, morphology, Balkans, Planariidae, Dendrocoelidae, Dugesiidae
Received January 21, 2015.

Revised August 3, 2015

Accepted October 23, 2015

\section{Abstract}

The aim of this paper is to describe morphological characteristics of freshwater triclads in Herzegovina and to provide a key for their identification based mainly on their external morphology. Our research is based on the freshwater triclads collected at 26 sites in Herzegovina, including 10 rivers, 6 springs and 1 lake.

Triclads were collected by hand and with the bait jar with a lid bearing many small perforations. Specimens were identified immediately after being collected or we transported them to the laboratory in termal containers with ice. The morphological features used for species identification in this key are: body coloration (color of the dorsal and ventral side), the size of the pharynx, the presence of tentacles and their location, number and position of the eyes in respect to each other and the body margin, and the shape of the head. Specimens were fixed using Steinmann's fluid and conserved in $70 \%$ alcohol. Inner morphological feature, shape of a penis, was used in determination of Polycelis tenuis and Polycelis nigra.

We collected a total of 11 species, belonging to 8 genera (Polycelis Ehrenberg, 1831, Crenobia Kenk, 1930, Phagocata Leidy, 1847, Planaria Müller, 1776, Dendrocoelum Örsted, 1844, Schmidtea Ball, 1974, Dugesia Girard, 1850, Girardia Ball, 1974) and 3 families.

The present study forms a baseline for future studies on the diversity and biogeography of Herzegovinian freshwater triclads.

\section{INTRODUCTION}

The order Tricladida comprises the free-living flatworms. Within

1 Tricladida, three infraorders have been recognized: Maricola (marine triclads), Paludicola (freshwater triclads), and Terricola (land triclads) (1), to which a new one, the Cavernicola was further added (2). Study based on molecular properties (3) indicates that the Terricola and Paludicola should be replaced with a clade Continenticola. This new clade comprises the families Planariidae Stimpson, 1857, Dendrocoelidae Hallez, 1892, Kenkiidae Hyman, 1937, Dugesiidae Ball, 1974 and Geoplanidae Stimpson, 1857 (4). We based our research on freshwater triclads belonging to the families Planariidae, Dendrocoelidae and $\mathrm{Du}$ gesiidae.

Despite some intensive studies (5-9), phylogeny, taxonomy and distribution of this group of organisms are still quite unknown and unexplained. The fauna of freshwater triclads in Bosnia and Herzegovina is not sufficiently explored. The latest surveys were conducted in the 1920s 
and 1930s (10-12). Lanfranchi and Papi (13), Italian zoologists, wrote about fauna of freshwater turbelarians in Limnofauna europea. However, they have not studied triclads, but they highlighted the fact that one could probably found a large number of new species in unexplored areas (Iberian and Balkan Peninsula). Dahm and Gurbault (14) reported 122 species of triclads in Europe and 42 of them were reported in the Balkans. It is significant that, as they said, the richest region is Southeast Europe, in particular the Balkan Peninsula, and southwestern regions of Europe. De Beauchamp (10) reported triclads in rivers Buna (Neodendrocoelum nausicae, Schmidt, Polycelis felina, Dalyell i Crenobia montenigrina, Mrezak), Jasenica (C. montenigrina, Mrezak) and Radobolja ( $C$. montenigrina, Mrezak). Fauna of the karst regions such as western Balkan Peninsula represents one of the most interesting in Europe (15). So far no keys for freshwater triclads were published in this region and the aim of this paper is to remedy this.

\section{SAMPLING SITES AND METHODS}

Altogether, 26 sites in Herzegovina were sampled, encompassing sites along the courses of rivers Neretva, Buna, Bunica, Bijela, Trebižat, Lištica, Jasenica, Radobolja, Studenčica and Crnašnica but also various habitats (springs and streams) in many of their tributaries (e.g. Crnašnica Vrilo, Crno Oko, Jasle, Arapi Vrilo, Rebrac etc.). Sampling sites, apart from spring Jasle in Masna Luka, belong to the so-called "lower Herzegovina“ with an average temperature of $15^{\circ} \mathrm{C}$ and an average rainfall of about $1500 \mathrm{~mm}$ (16). Details on geographic position of sampling sites and their photos are presented in Fig. 1 and Table 1 .

Freshwater triclads were collected by hand between April and December 2011. It is the most convenient, most common and also the easiest way for their collecting. Only at two sites, source of river Buna and Crno Oko spring, where the water depth was greater and it was impossible to collect the specimens by hand, specimens were collected as described in Kenk (17). The bait jar with a lid bearing many small round perforations is submerged, together with some anchoring ballast, and attached by a line to a float. After 24 hours, triclads will be found inside the jar. Where possible, during the fieldwork we processed more stations of the same river - e.g. source, middle and lower reach, to include all available habitats and their respective characteristic species that occur at different parts of the river. Altogether, samples were collected at 26 sites, including 10 rivers, 6 springs and 1 lake.

\section{Fixation, identification and handling tips}

Many triclads are very sensitive to temperature fluctuation and if the water warms up too much, triclads disintegrate easily. Following species collected in studied

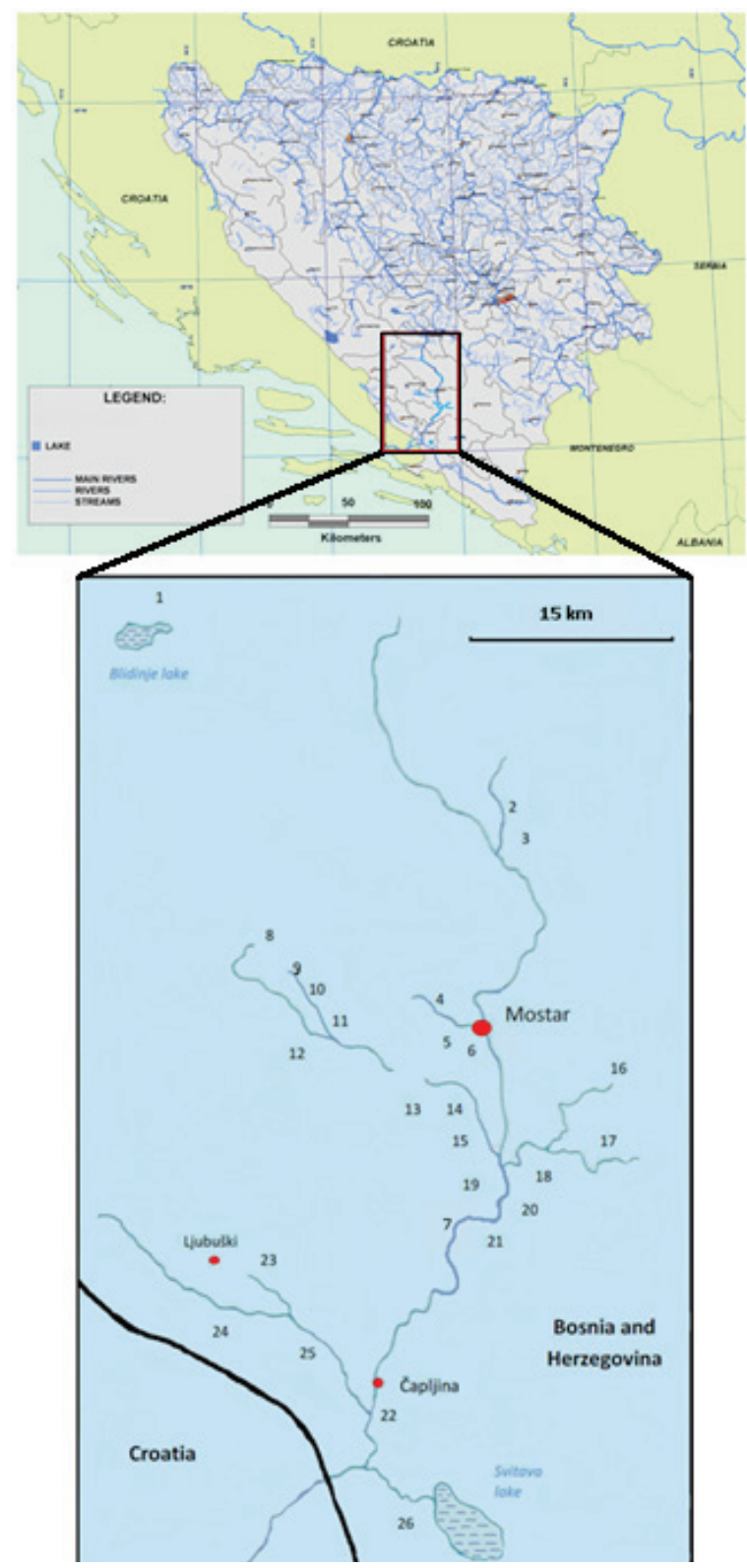

Figure 1. Sampling region of Herzegovina.

area belong in this group, Polycelis felina, Crenobia alpina and species belonging to genus Phagocata. Those species must be identified immediately after being collected or they should be transported to the laboratory in termal containers with ice.

The specimens of freshwater triclads are often changed after fixation and conservation. So, when it is possible the best practice is to observe, analyse and record external morphological features on living specimens. Although there are several methods for triclads fixation described in Reynoldson \& Young (18), Steinmann's fluid (mixture of $300 \mathrm{ml}$ concentrated nitric acid (65-70\%), $300 \mathrm{ml}$ saturated solution of mercuric chloride in $5 \%$ sodium chloride and $300 \mathrm{ml}$ distilled water) proved to be the best medium 


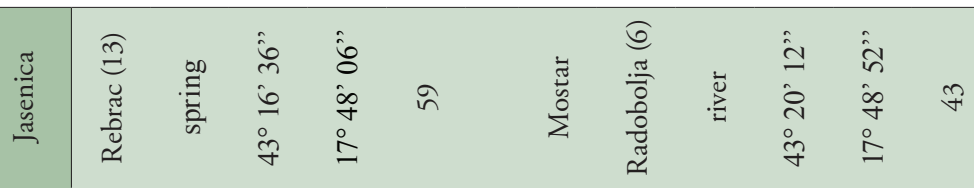

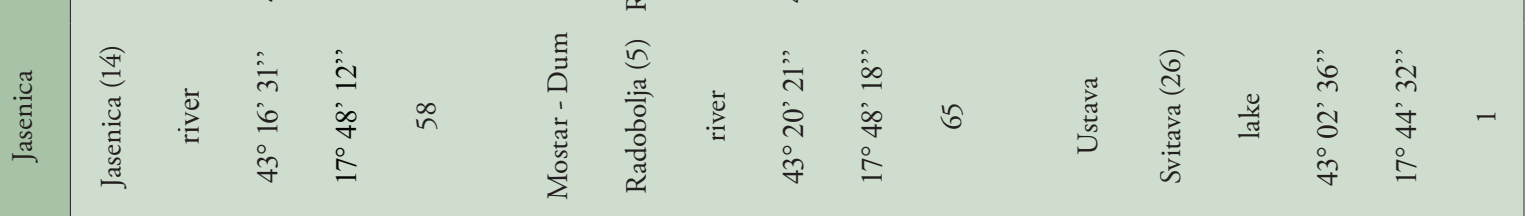

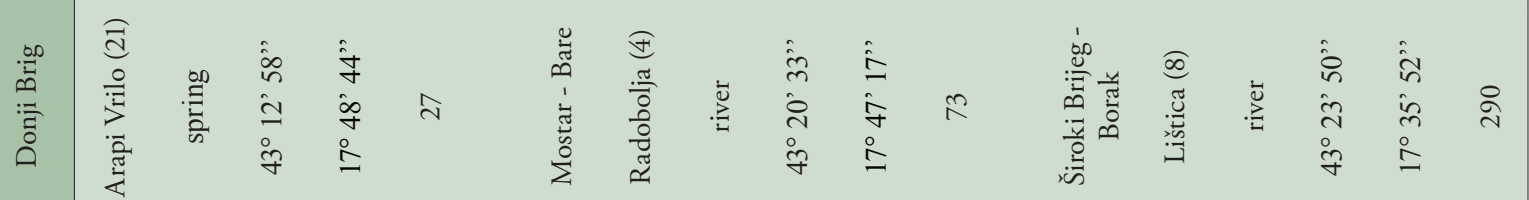

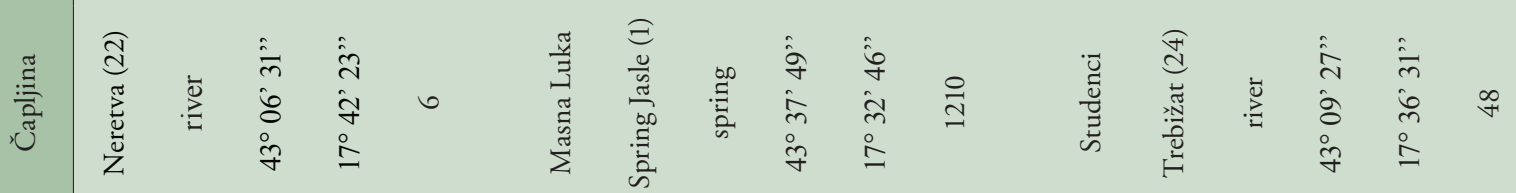

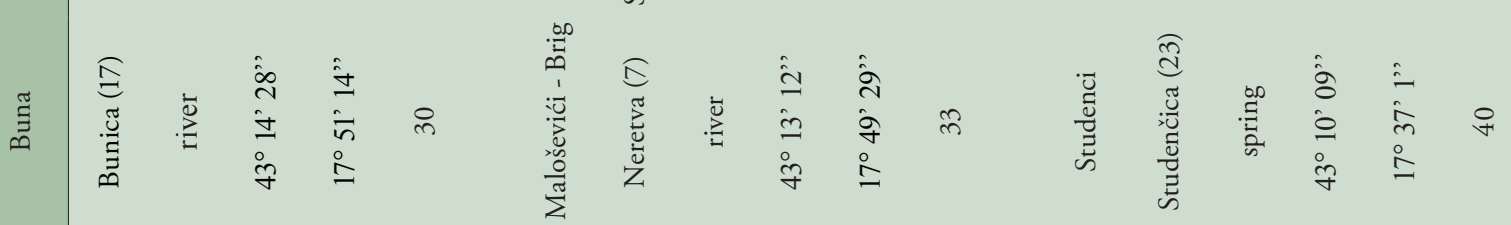

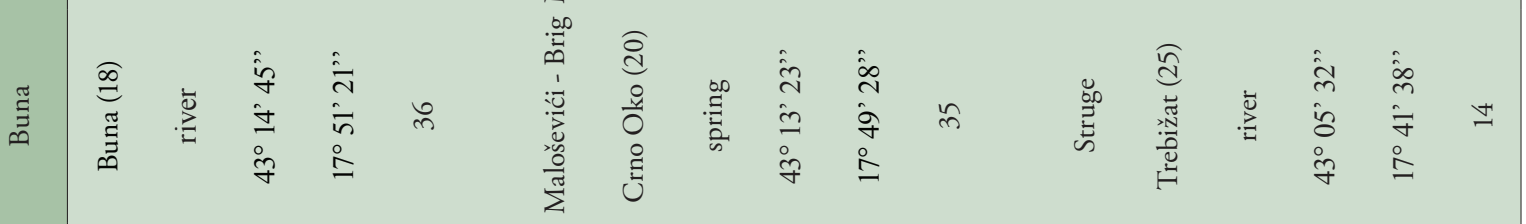

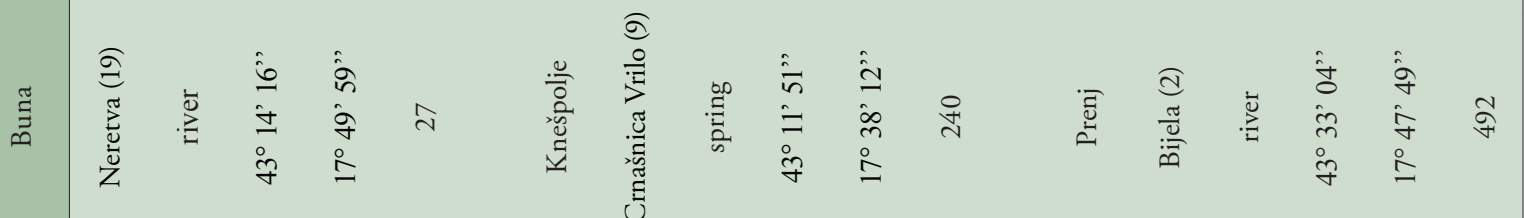

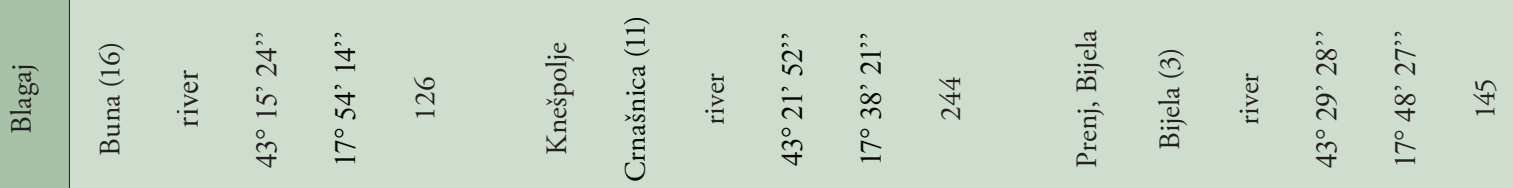

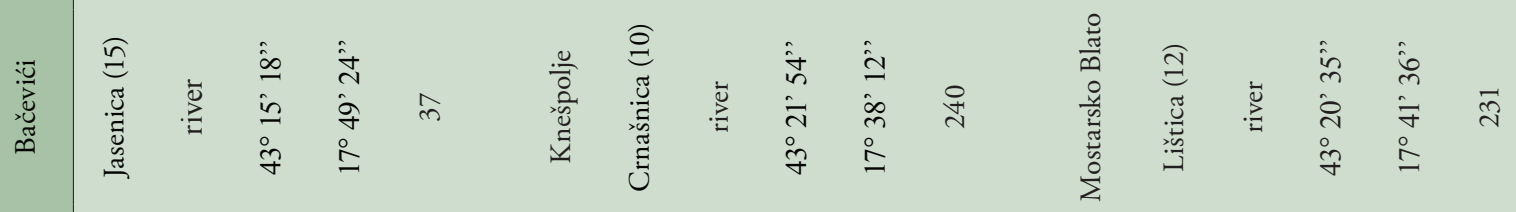

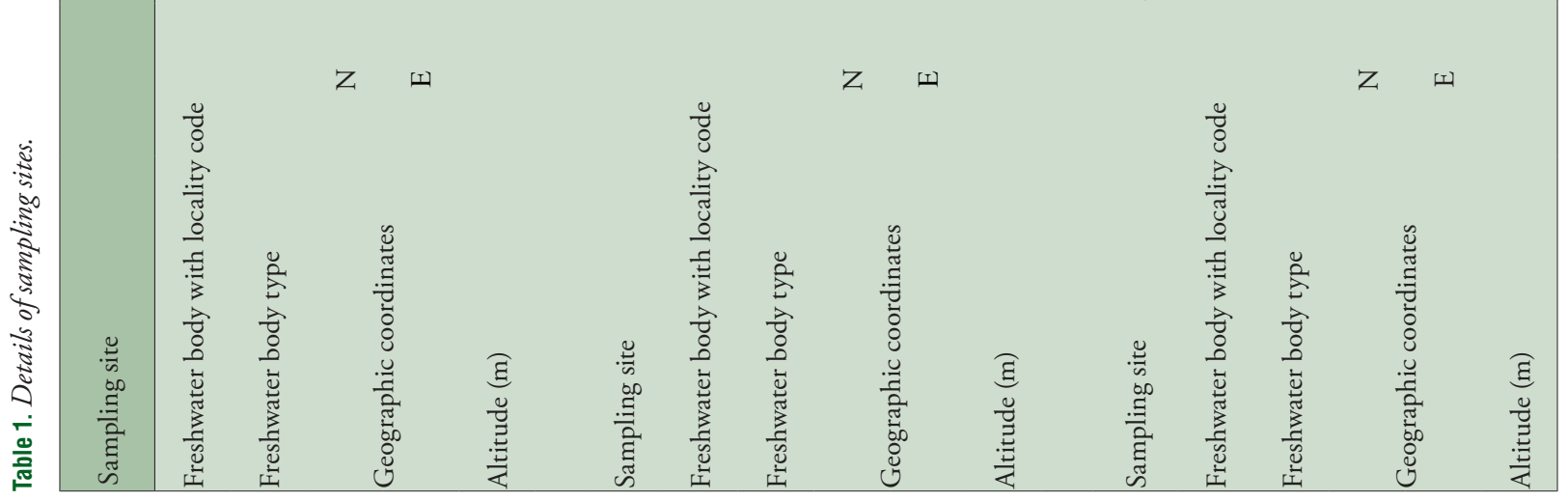



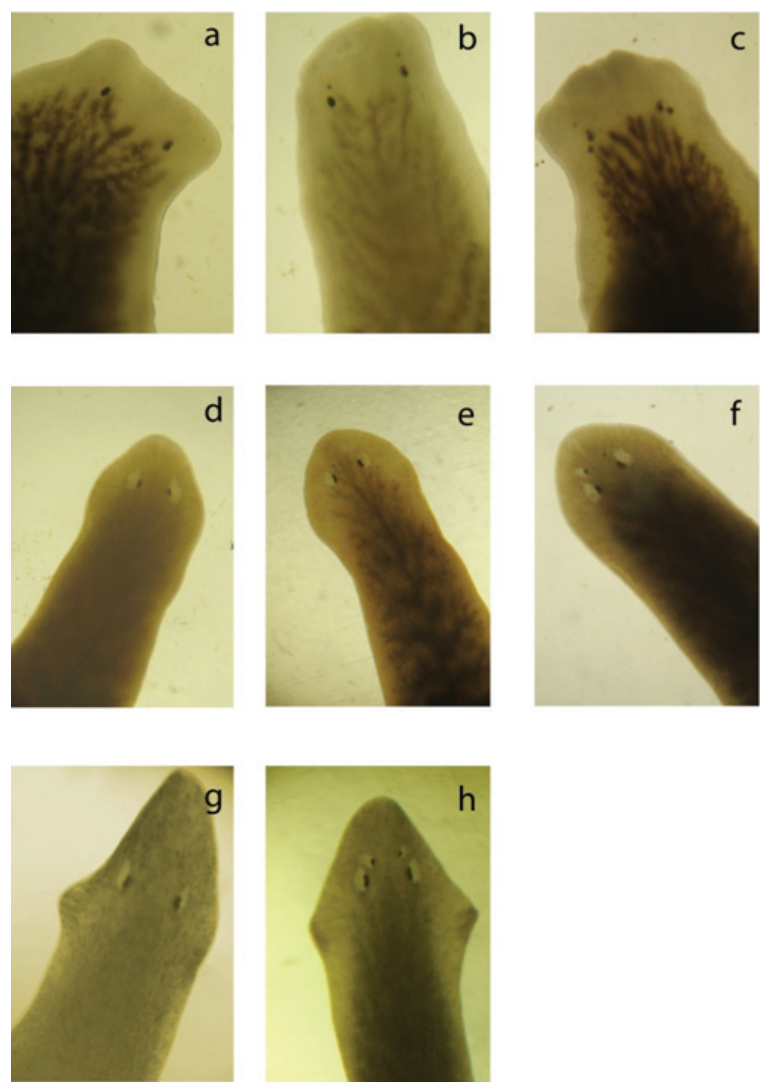

Figure 2. Heads of Dendrocoelum sp. $(a, b, c)$, Schmidtea polychroa $(d, e, f)$ and Dugesia sp. $(g, h)$ showing specimens with different number of eyes.

for fixation of aquatic triclads. After the fixation, specimens were conserved in $70 \%$ alcohol.
The morphological features used in identification in this key are: body coloration (color of the dorsal and ventral side), the size of the pharynx, the presence of tentacles and their location, number and position of the eyes in respect to each other and the body margin, and the shape of the head. The size of the body and pharynx, as well as the distance between the eyes and the distance between the eyes and body margins are the features best maintained on fixed specimens. Inner morphological feature, shape of a penis, was used in determination of Polycelis tenuis and Polycelis nigra.

Some specimens of Dendrocoelum sp., Dugesia sp. and Schmidtea polychroa have more than two eyes (Fig. 2). In specimens of genus Dugesia feature when animals have more than two eyes can be related with the age of an animal, while in the specimens of genus Dendrocoelum this feature can be important for species determination (19).

Identification was based on the available literature (e.g. $10,11,15,18,20-24)$.

\section{Notes on the species}

We collected freshwater triclads of the following genera: Polycelis Ehrenberg, 1831, Crenobia Kenk, 1930, Phagocata Leidy, 1847, Planaria Müller, 1776, Dendrocoelum Örsted, 1844, Schmidtea Ball, 1974, Dugesia Girard, 1850, Girardia Ball, 1974. According to Stanković (12) triclads fauna of western Balkan is divided into three groups, i) widespread Palearctic species, ii) species that occur only in Europe and iii) endemic Balkan species. From the first group in Herzegovina we have reported three species, Crenobia alpina, Dugesia sp. and Polycelis nigra. Polycelis felina, Schmidtea lugubris, Schmidtea poly-

TABLE 2.

A list of species at each locality.

\begin{tabular}{|c|c|c|c|c|c|c|c|c|c|c|c|c|c|c|c|c|c|c|c|c|c|c|c|c|c|c|}
\hline \multirow{2}{*}{ Species } & \multicolumn{26}{|c|}{ Locality code number } \\
\hline & 1 & 2 & 3 & 4 & 5 & 6 & 7 & 8 & 9 & 10 & 11 & 12 & 13 & 14 & 15 & 16 & 17 & 18 & 19 & 20 & 21 & 22 & 23 & 24 & 25 & 26 \\
\hline Crenobia alpina & $\mathrm{x}$ & & & & & & & & & & & & & & & & & & & & & & & & & \\
\hline Dendrocoelum sp. & & & & & & $\mathrm{x}$ & $\mathrm{x}$ & & & $\mathrm{x}$ & $\mathrm{x}$ & $\mathrm{x}$ & $\mathrm{x}$ & $\mathrm{x}$ & $\mathrm{x}$ & & $\mathrm{x}$ & & & $\mathrm{x}$ & $\mathrm{x}$ & $\mathrm{x}$ & & & & \\
\hline Dugesia sp. & & & & & & & & & & & & & & & & & & & & $\mathrm{x}$ & & & & & & \\
\hline Girardia tigrina & & & & & & & & & & & & & & & & & & & $\mathrm{x}$ & & & & & & $\mathrm{x}$ & \\
\hline Phagocata bosniaca & & & & & & & & & $\mathrm{x}$ & & & & & & & & & & & & & & & & & \\
\hline Phagocata dalmatica & & & & & & & & & & & & & & & & & & & & & & & $\mathrm{x}$ & & & \\
\hline Planaria torva & & & & & & & & & & & & & & & & & & & & & & & $\mathrm{x}$ & $\mathrm{x}$ & $\mathrm{x}$ & $\mathrm{x}$ \\
\hline Polycelis felina & & & & & & & $\mathrm{x}$ & $\mathrm{x}$ & & & & & & & & & $\mathrm{x}$ & & & $\mathrm{x}$ & & $\mathrm{x}$ & $\mathrm{x}$ & & & \\
\hline Polycelis nigra & & & & & & & $\mathrm{x}$ & & & & & & & & & & & & & $\mathrm{x}$ & & & & & & \\
\hline Polycelis tenuis & & & & & & & & & & & $\mathrm{x}$ & $\mathrm{x}$ & $\mathrm{x}$ & $\mathrm{x}$ & $\mathrm{x}$ & & & & & & & & & & & \\
\hline Schmidtea polychroa & & & & & & $\mathrm{x}$ & & & & & & & & & & & & & & $\mathrm{x}$ & & & $\mathrm{x}$ & $\mathrm{x}$ & $\mathrm{x}$ & $\mathrm{x}$ \\
\hline Number of species & 1 & 0 & 0 & 0 & 0 & 2 & 3 & 1 & 1 & 1 & 2 & 2 & 2 & 2 & 2 & 0 & 2 & 0 & 1 & 5 & 1 & 2 & 4 & 2 & 3 & 2 \\
\hline
\end{tabular}


chroa, Planaria torva, Polycelis tenuis, Dendrocoelum lacteum, D. album, Phagocata albissima and Atrioplanaria racovitzai belong to the second group, only European species. From those nine species, we have reported four of them, P. felina, S. polychroa, $P$. torva and P. tenuis. From the third group, two endemic species are present in studied area, $P$. dalmatica and $P$. bosniaca. A list of collected species at each locality is given in Table 2 .

\section{Family Planariidae}

Polycelis felina Dalyell, 1814 (Fig. 3a) is widespread throughout Europe (14), and is one of the most widespread species of freshwater triclads in Herzegovina. P. felina tolerates higher temperatures better than $C$. alpina and usually inhabits the lower parts of the rivers and streams where the water is warmer and where the water current is slower $(25,26)$. P. felina has numerous eyes placed along the anterior part of the head and along the lateral margins of the body. Two long and narrowed tentacles are situated laterally on the head. Between head and the posterior part of the body there is a slight constriction. Color of the body, ranges widely from red (individuals recorded at the source of the river Lištica), light and dark brown, to black (individuals recorded in rivers Bunica and Neretva). The average size of the body is $14 \mathrm{~mm}$. Size of the pharynx is a little bit more than half of the total body length.

Crenobia alpina Dana, 1766 (Fig. 3b) is generally associated with high altitude and low temperature, although it also occurs at sea-level in streams that are shaded and cool (27). We collected the species only at one site, in stream Jasle at $1210 \mathrm{~m}$ altitude. Specimens of C. alpina have two eyes situated in non pigmented cup. The distance between the eyes is shorter than the distance between the eyes and body margin. The eyes are situated far back on the head. Tentacles are pointed and located laterally on the head. Although in literature (e.g, 22) individuals of different colors (gray, brown or black) were reported, all of our sampled individuals were black. Ventral side is paler than the dorsal. Average size of the body is $11 \mathrm{~mm}$. Size of the pharynx is half of the total body length.

Polycelis nigra Müller, 1774 (Fig. 3c) has been reported from various localities in Europe and is considered as one of the most widespread triclad on this continent (28). Although black and brown specimens of $P$. nigra were reported (e.g. 18), all of our specimens were black. Dorsal and ventral sides of the body are equally pigmented. They have numerous eyes along the anterior and marginal side of the body. Average size of the body is $8 \mathrm{~mm}$ and the size of the pharynx is a little bit longer than the one half of the total body length.

Specimens of Polycelis tenuis Ijima, 1884 (Fig. 3d) are very similar to the specimens of $P$. nigra. Those animals also have numerous eyes with the same position as in $P$. nigra. Color of the body comes in all shades of brown. Pigment is not equally distributed and specimens often
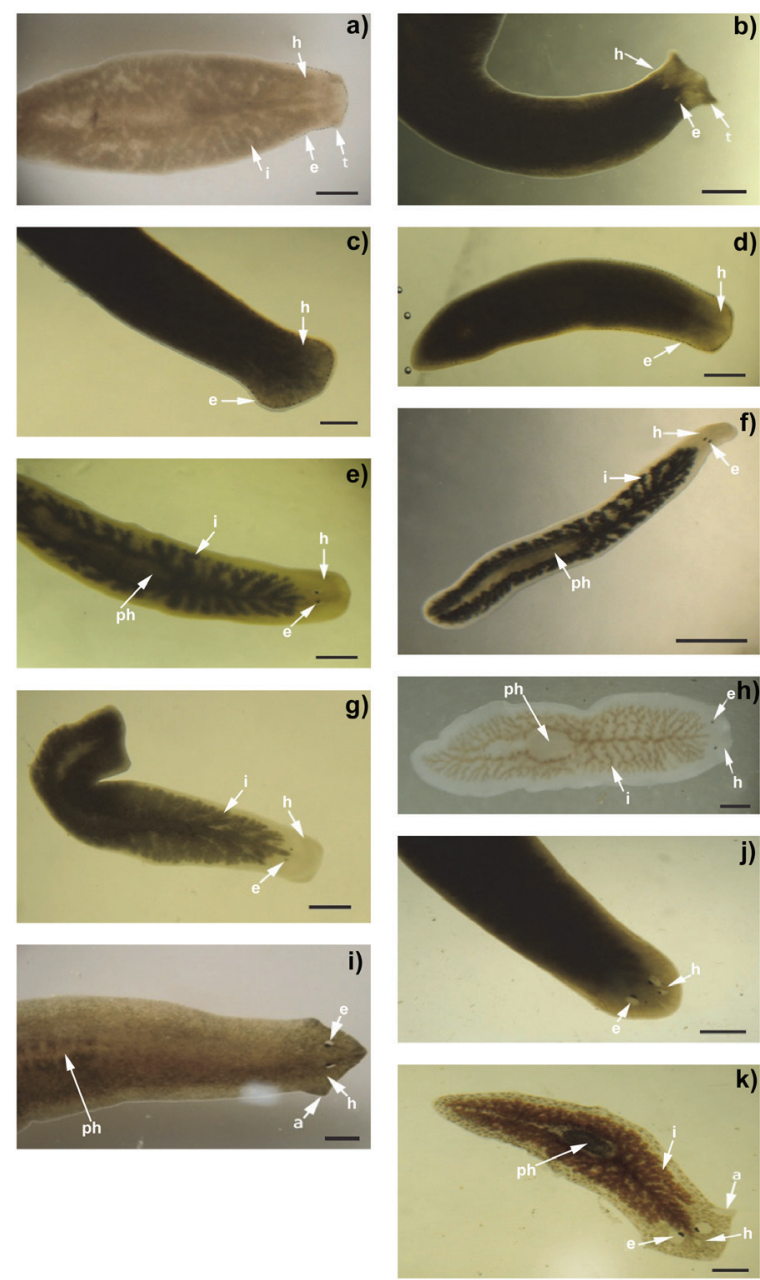

Figure 3. Dorsal view of Polycelis felina (a), Crenobia alpina (b), Polycelis nigra (c), Polycelis tenuis (d), Planaria torva (e), Phagocata bosniaca (f), Phagocata dalmatica (g), Dendrocoelum sp. (h), Dugesia sp. (i), Schmidtea polychroa (j), Girardia tigrina (k). Abbreviations: a: auricle, e: eye; $h$ : head; $i$ : intestinal caecum; $p h$ : pharynx; $t$, tentacle; Scale bar: $1 \mathrm{~mm}$.

have darker brown line along the body. Ventral and dorsal sides of the body are equally colored. Head is not clearly separated from the rest of the body. Average size of the body is $9 \mathrm{~mm}$ and the size of the pharynx is a little bit longer than the one half of the total body length.

One could find difficult to determine whether specimens belong to $P$. tenuis or $P$. nigra and they are often present together in studied area. They can be distinguished on the basis of their reproductive system, more accurately structure of their penis. Specimens of $P$. tenuis have elongated penis with or without two adenodactyls, while specimens of $P$. nigra have short, barrel-shaped penis (Fig. 4) (22). The penis can be observed by cutting a live specimen with a sharp scalpel immediately distal to the pharynx and mouth opening and placing the specimen on a glass slide with ventral side facing up. Then place 

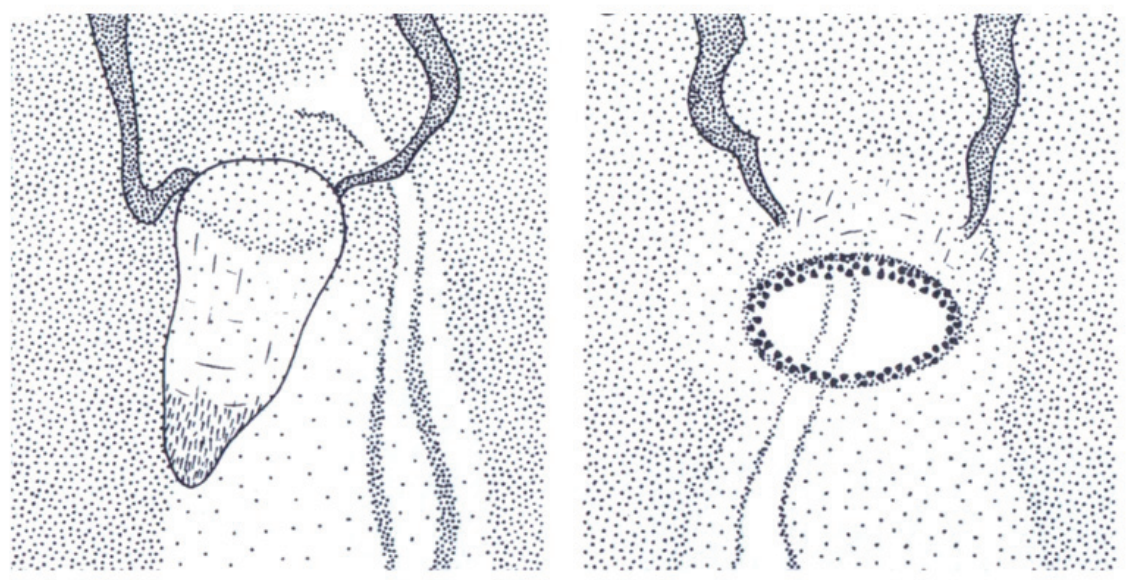

Figure 4. Shape of penis: elongated penis of P. tenuis (a); barrel-shaped penis of P. nigra (b) (22).

the coverslip, gently press and observe preparation using a microscope.

The genus Phagocata Leidy, 1847 has a Holarctic distribution (29). The nomenclatural and systematic history of the genus Phugocata Leidy, 1847 has been reviewed by Dahm $(30,31)$ and Ball and Gourbault (32). As a result of previous studies, current taxonomic practice generally gives priority to the generic name Phagocata, thus assigning the status of junior synonym to Albiplanaria Komarek, 1926, Fonticola Komarek, 1926, Atrioplanaria Beauchamp, 1932, and Penecurva Livanov and Zabusova, 1940 (23). However, it has already been recognized by previous workers that the genus Phagocata subsumes a rather heterogeneous group of species that upon further study may perhaps be rearranged into several more natural (sub)groups (30, 31, 33-36).

Two species of this genus are recorded in Herzegovina, Phagocata bosniaca Stanković, 1926 (Fig. 3f) and Phagocata dalmatica Stanković and Komarek, 1927 (Fig. 3g). Both are small, white animals with two eyes. Almost all other known European species of Phagocata are also unpigmented except for $P$. armeniaca (37) (Armenia and central Turkey), P. maculata (12) (Lake Ohrid) and P. ullala (29). Anterior side of the head is flat with no tentacles. Lateral sides of the body are almost parallel. Distance between the eyes is smaller than the distance between the eyes and lateral body margins, and the distance between the eyes and the anterior body margin is three times greater than the distance between the eyes. Size of the pharynx reaches one fifth of the total body size. The only difference between those two species is the length of the anterior branch of the intestine. In P. bosniaca specimens this branch doesn't reach the eyes, while in the $P$. dalmatica anterior intestine branch reaches the area of the eyes. Average size of those animals is about $6 \mathrm{~mm}$. We recorded those species in stream sources in deep shade where the water temperature has no significant fluctuations. Water depth at these sites never exceeded half a meter.
Planaria torva (Fig. 3e) was originally described by $\mathrm{O}$. F. Müller in 1774 under the generic name Fasciola (38). Those animals don't have tentacles. Head is flat, slightly rounded on its lateral sides. Animals have two eyes situated in non pigmented cups. Distance between the eyes is smaller than the distance between the eyes and the body margins. Dorsal color is usually in a shade of brown and ventral side is paler. Animals have darker brown line along the body. Average size of the body is $10.5 \mathrm{~mm}$ and the length of the pharynx is half of the total body length.

\section{Family Dendrocoelidae}

This is the largest family of aquatic triclads, with at least 24 genera comprising 213 species (39). One genus, Dendrocoelum, is present in Herzegovina. Our preliminary results of copulatory apparatus of genus Dendrocoelum showed that there is much greater diversity of this genus in Herzegovina than previously thought. Those species are difficult to determine only on the basis of their external appearance. So, the further analyses of their copulatory apparatuses are required. That is the main reason why the determination on the basis of morphological traits in this key stops at the genus level. Collected specimens of Dendrocoelum sp. (Fig. 3h) usually had two eyes, but we also recorded representatives with more eyes-up to five (Figure 2. a-c). The distance between eyes is twice as long as the distance between the eyes and the body margin. Specimens have small tentacles. The color of the body is white. Some specimens reach up to $30 \mathrm{~mm}$. We recorded species of this genus on numerous stations in Herzegovina. However, their abundance is not as high as for example in P. felina or G. tigrina.

\section{Family Dugesiidae}

The family Dugesiidae comprises the freshwater triclads, with a worldwide distribution (3). Three out of four genera found in Europe (5, 6), have their representatives in Herzegovina (Dugesia, Schmidtea and Girardia). 
Girardia originally had an American distribution, although one species, Girardia tigrina Girard, 1850 (Fig. $3 \mathrm{k}$ ) was introduced to Europe at the beginning of the $20^{\text {th }}$ century (40). This is the first record of G. tigrina in Herzegovina and it supports that the species originally distributed in America quickly spreads throughout Europe. The species was collected at two sites, in rivers Neretva and Trebižat. Both populations were asexual. The head in this species is triangular with laterally positioned auricles. All collected specimens have two eyes as opposed to the species Dugesia sp. and S. polychroa whose specimens with three or four eyes were recorded (Figure 2. d-h). The distance between eyes is shorter than the distance between the eyes and the body margin. Dorsal side of the body is spotted and ventral is paler. The average size of the body is $7 \mathrm{~mm}$. Pharynx is colored and its size is onesixth of the body length.

Dugesia is a species-rich genus, in contrast with Schmidtea. It includes about 80 described species with a wide distribution. Of those 80 species, more than 20 occur in Europe and in the Mediterranean area (40). Several factors render the number and distribution of Dugesia species uncertain. They are externally very similar and many of their populations are triploid and they do not develop reproductive system or copulatory apparatus. Those two features make proper species assignment impossible. Specimens of Dugesia sp. (Fig. 3i) have triangular head with laterally positioned auricles. Usually they have two eyes, but the specimens with three or four eyes were also recorded. Dorsal side of the body is uniformly brown and the ventral side is paler. Some of the specimens reach up to $23 \mathrm{~mm}$.

Schmidtea polychroa Schmidt, 1861 (Fig. 3j) is widely distributed in Europe (28). Specimens of S. polychroa have rounded head with the lack of tentacles. They usually have two eyes but we recorded and specimens with three or four eyes. Distance between the eyes is one and a half time greater than the distance between the eyes and the body margin. Dorsal side of the body is dark brown and the ventral side is paler. A great variability in body size at different sampling sites is recorded. Specimens collected in river Radobolja are the biggest freshwater triclads recorded in Herzegovina. Some specimens reach up to $43 \mathrm{~mm}$. Average size of those animals on the other sampling sites is $14 \mathrm{~mm}$.

\section{The key to the freshwater triclads of Herzegovina}

The key, presented below, is intended for determining the freshwater triclads, and is based on external morphology of specimens. Inner morphological feature, structure of penis, was used only to distinguish species $P$. tenuis and $P$. nigra. The size of the body and pharynx, as well as the distance between the eyes and the distance between the eyes and body margins were measured on fixed specime
1. - Head with awl-shaped tentacles of variable length.

- Head without awl-shaped tentacles.

2. - Color of the dorsal side variable, but usually a shade of dark grey to black. Ventral side of the body paler. Two eyes.

Crenobia alpina

- Dorsal color usually a shade of brown, grey or black. Ventral surface paler. Eyes numerous, placed along the anterior and lateral margins.

Polycelis felina

3. - One pair of eyes (occasionally one can find animals with three, four or five eyes).

- Eyes numerous along the margins or around the head or anterior part of the body.

4. - Non pigmented species. 6

- Pigmented species.

5. - Pigment usually distributed uniformly. Animals commonly black. Ventral surface same color as the dorsal. Elongated penis (see note in previous section).

Polycelis nigra

- Pigment is giving a mottled pattern. Animals commonly different shade of brown. Mid-dorsal streak of darker brown is present. Ventral surface same color as the dorsal. Barrel-shaped penis (see note in previous section).

Polycelis tenuis

6. - Head with slight development of projections situated latero-anteriorly. Eyes situated further from each other, distance between eyes greater than that from the eyes to the margins of the head. Usually longer than $10 \mathrm{~mm}$, some of the animals may reach $30 \mathrm{~mm}$ in length. Animals with three, four or five eyes are frequent.

Dendrocoelum sp.

- Head truncate, slightly rounded on its margins. Eyes close together distance between eyes less than that from the eyes to the anterior and side margins. Usually not longer than $10 \mathrm{~mm}$. 
7. - Dorsal color usually a shade of brown, grey or black. Ventral surface paler. Head truncate, slightly rounded on its margins. Usually not longer than $12 \mathrm{~mm}$.

Planaria torva

- Head triangular.

8. - Anterior branch of intestine doesn't reach eyes. It is not branched. Animals up to $7 \mathrm{~mm}$ long.

Phagocata bosniaca

- Anterior branch of intestine reaches eyes. It is not branched. Animals up to $10 \mathrm{~mm}$ long.

Phagocata dalmatica

9. - Head markedly triangular.

- Head more rounded. Eyes situated in a non pigmented cup. Distance between eyes greater than that from the eyes to the margins of the head. Animals with three or four eyes could be found. Body color in different shades of brown. Ventral side paler. Usually not longer than $25 \mathrm{~mm}$, but individuals of up to $43 \mathrm{~mm}$ were recorded.

Schmidtea polychroa

10. - Anterior margin and lateral auricles sharply pointed. Dorsal surface of the body blotchy with grey and brown spots. Pharynx pigmented.

Girardia tigrina

- Dorsal surface brown, uniformly pigmented. Animals with more than two eyes (three or four) can be found.

Dugesia sp.

\section{Final remarks}

De Beauchamp (10) reported triclads in rivers Buna (Neodendrocoelum nausicae, Schmidt, Polycelis felina, Dalyell i Crenobia montenigrina, Mrezak), Jasenica ( $C$. montenigrina, Mrezak) and Radobolja (C. montenigrina, Mrezak). However, even though all three rivers were involved in our studied area, we didn't collect any of those species at mentioned localities.

Although the structure of the reproductive system is considered to be a reliable method of triclads determination, there are species that have the same structure of the reproductive system but differ in some other characteristics. The determination of Phagocata stankovici and Phagocata ochridana as separate species was done on the basis of few morphological differences. In $P$. ochridana the anterior ramus of the intestine ends at, or somewhat behind, the level of the eyes. In P. stankovici the end of the anterior intestinal trunk forms an unbranched extension that reaches in the midline to a level anterior to the eyes. This seems to be the only essential external character that separate $P$. ochridana from $P$. stankovici. Later on, this determination was confirmed with enzyme electrophoresis (41). External morphological features should not be omitted when describing species and determinate triclads but when it is posible the best approach in triclads determination is a combination of morphological features, structure of the reproductive system, as well as molecular analyzes. Our present analysis forms the first step towards a comprehensive morphological datamatrix of freshwater triclads.

Our knowledge of triclads in Herzegovina is still in its infancy. Through this article we aim to guide and facilitate future studies on this diverse group of animals. We hope that our present study will stimulate scientists to include triclads in their studies. Keeping in mind the water richness of Bosnia and Herzegovina, we believe that with more extensive field work and with intensive studies the number of reported species in this area would increase significantly.

\section{REFERENCES}

1. HALLEZ P 1890 Catalogue des Turbellaries (Rhabdocoelides, Tricladides et Polycladides) du Nord de la France et de la Côte Boulonnaire. Rev. Biol. Nord France 2: 1-179

2. SLUYS R 1990 A monograph of the Dimarcusidae (Platyhelminthes, Seriata, Tricladida). Zool. Scr. 19: 13-29 http://dx.doi. org/10.1111/j.1463-6409.1990.tb00237.x

3. CARRANZA S, LITTLEWOOD D T J, CLOUGH K A, RUIZTRILLO I, BAGUNÀ J, RIUTORT M 1998 A robust molecular phylogeny of the Tricladida (Platyhelminthes, Seriata) with a discussion on morphological synapomorphies. Proc. R. Soc. Lond. B. 265: 631-640

4. SLUYS R, KAWAKATSU M, RIUTORT M, BAGUÑÀ J 2009 A new higher classification of planarian flatworms (Platyhelminthes, Tricladida). J. Nat. Hist. 43 29-30: 1763-1777

5. BAGUNȦ̀ J, CARRANZA S, PALA M, RIBERA C, GIRIBET G, ARNEDO M A, RIBAS M, RIUTORT M 1999 From morphology and karyology to molecules. New methods for taxonomical identification of asexual population of freshwater planarians. A tribute to professor Mario Benazzi. Ital. J. Zool. 66: 207-214

6. RIUTORT M, ÁLVAREZ-PRESAS M, LÁZARO E, SOLÀ E, PAPS J 2012 Evolutionary history of the Tricladida and the Platyhelminthes: an up-to-date phylogenetic and systematic account. Int. J. Dev. Biol. 56: 5-17 http://dx.doi.org/10.1387/ijdb.113441mr

7. SLUYS R, KAWAKATSU M, WINSOR L 1998 The genus Dugesia in Australia, with its phylogenetic analysis and historical biogeography (Platyhelminthes, Tricladida, Dugesiidae). Zool. Scr. 27: 273-290 http://dx.doi.org/10.1111/j.1463-6409.1998.tb00461.x

8. BAGUÑÀ J, CARRANZA S, PAPS J, RUIZ-TRILLO I, RIUTORT M 2001 Molecular taxonomy and phylogeny of Tricladida. In: Littlewood, D. T. J., Bray, R. D. (Eds.), The Interrelationships of the Platyhelminthes. Taylor \& Francis, UK, CL, p 49-56

9. VILLA-FARRÉ M, SLUYS R, ALMAGRO Í, HANDBERGTHORSAGER M, ROMERO R 2011 Freshwater planarians (Platyhelminthes, Tricladida) from the Iberian Peninsula and Greece: new records, seven new species, diversity and ecology. Zootaxa. 2779: 1-38

10. DE BEAUCHAMP P 1937 Turbellaries Tricladés de Yougoslavie récoltés par MM. Remy et Hubault. B. Soc. Zool. Fr. 62: 351-365 
11. STANKOVIĆ S, KOMÁREK J 1927 Die Süsswasser - Tricladen des Westbalkans und die zoogeographischen Probleme dieser Gegend. Zool. Jahrb. Abt. Syst. Ökologie. Geograph. Tiere. 53: 591674

12. STANKOVIĆ S 1934 Über die Verbreitung und Ökologie der Quellentricladen auf der Balkanhalbinsel (Ein Beitrag zur Geschichte der Susswasserfauna des Balkans). Zoogeographica. 2 (2): 147-203

13. LANFRANCHI A, PAPI F 1978 Turbellaria (exl. Tricladida). In Limnofauna europaea (J. Illies, ed.). Gustav Fischer Verlag, Stuttgart. p 5-15

14. DAHM A G, GOURBAULT N 1978 Tricladida et Temnocephalida (Turbellaria). In Limnofauna Europea (Ed. J. Illies). Stuttgart and New York. Gustav Fischer. 16-20

15. MUČIBABIĆ S 1980 Fauna Turbellaria Bosne i Hercegovine. Knjiga XLVII. Akademija nauka i umjetnosti Bosne i Hercegovine. Sarajevo. 43-51

16. RADULOVIĆ Ž 1981 Hercegovina. NIRO Privredni vjesnik. Zagreb. 25-42

17. KENK R 1972 Freshwater planarians (Turbellaria) of North America. Biota of Fresh-water Ecosystems, Identification Manual. U.S. Environmental Protection Agency, Washington, D.C. p 81

18. REYNOLDSON T B, YOUNG J O 2000 A key to the freshwater triclads of Britain and Ireland. Freshwater Biological Association. $\mathrm{p} 72$

19. STOCCHINO G A, SLUYS R, MARCIA P, MANCONI R 2013 Subterranean aquatic planarians of Sardinia, with a discussion on the penial flagellum and the bursal canal sphincter in the genus Dendrocoelum (Platyhelminthes, Tricladida, Dendrocoelidae). Journal of Cave and Karst Studies, v. 75, no. 2, p. 93-112

20. TYLER S, SCHILLING S, HOOGE M, BUSH L F 2005 Turbellarian taxonomic database. Version 1.4. http://turbellaria.unimaine.edu

21. SCHOCKAERT E R, HOOGE M, SLUYS R, SCHILLING S, TYLER S, ARTOIS T 2007 Global diversity of free living flatworms (Platyhelminthes, „Turbellaria“) in freshwater. Hydrobiologia 595: 41-48

22. BALL I R, REYNOLDSON T B 1981 British planarians. Cambridge University Press, p 141

23. KENK R 1974 Index of the Genera and Species of the Freshwater Triclads (Turbellaria) of the World. Sm. C. Zool. 183: p 90

24. KENK R 1978 The Planarians (Turbellaria: Tricladida, Paludicola) of Lake Ohrid in Macedonia. Sm. C. Zool. 280: p 49 http://dx.doi. org $/ 10.5479 /$ si.00810282.280

25. PATTÉE E 1966 Coefficient thermiques et écologie de quelques Planaries d'eau douce. I. Tolérance des adultes. Ann. Limnol. 2: 469-475 http://dx.doi.org/10.1051/limn/1966010

26. WRIGHT J F 1974 Some factors affecting the distribution of Crenobia alpina (Dana), Polycelis felina (Dalyell) and Phagocata vitta (Duges) (Platyhelminthes) in Caernarvonshire, North Wales. Freswat. Biol. 4: 31-59 http://dx.doi.org/10.1111/j.1365-2427.1974. tb00938.x
27. WRIGHT J F 1972 The distribution of stream-dwelling triclads (Platyhelminthes) in North Wales. Freshwat. Biol. 2: 57-64 http:// dx.doi.org/10.1111/j.1365-2427.1972.tb01580.x

28. HARRATH A H, SLUYS R, MERZOUG D, YACOUBIKHEBIZA M, ALWASEL S, RIUTORT M 2012 Freshwater planarians (Platyhelminthes, Tricladida) from the Palearctic section oft he African continent: new records, with the description of a new species. Zootaxa. 3182: 1-15

29. SLUYS R, RIBAS M, BAGUÑÀ J 1995 Taxonomy, ecology, and karyology of a new species of Phagocata from Spain, with a discussion on the phylogenetic systematics of the genus Phagocata s.l. (Platyhelminthes, Tricladida, Paludicola) Can. J. Zool. 73: 557-568 http://dx.doi.org/10.1139/z95-064

30. DAHM A G 1958 Taxonomy and ecology of five species groups in the family Planariidae (Turbellaria Tricladida Paludicola). Nya Litografen, Malmo, Sweden

31. DAHM A G 1964 The taxonomic relationships of the European species of Phagocata $(?=$ Fonticola $)$ based on karyological evidence. Ark. Zool. 16: 481-509

32. BALL I R, GOURBAULT N 1975 The morphology, karyology and taxonomy of a new freshwater planarian of the genus Phagocata from California (Platyhelminthes: Turbellaria). R. Ont. Mus. Life Sci. Contrib. No. 105

33. DE BEAUCHAMP P 1932 Biospeologica LVI: Turbellariés, Hirudinées, Branchiobdellidés. Arch. Zool. Exp. Gen. 73: 113380

34. DE BEAUCHAMP P 1939 La systématique et l'éthologie des Fonticola (Turb. Triclades). Vestn. Cesk. Spol. Zool. VI-VII: 91 $-96$

35. KENK R 1953 The freshwater triclads (Turbellaria) of Alaska. Proc. U.S. Natl. Mus. 103: 163-186 http://dx.doi.org/10.5479/ si.00963801.103-3322.163

36. GOURBAULT N 1972 Recherches sur les triclades paludicoles hypogés. Mém. Mus. Natl. Hist. Nat. Ser. A, 73: 1-249 + 3 plates

37. KOMÀREK J 1916 Triclady z Kavkazu a Armenie. I. Dendrocoelum longipenis n. sp., Planaria armeniaca n.sp. Rozpr. Cesk. Akad. Cisare Frantiska Josefa Vedy Slovenost Umeni Ser. 2, 25(28)

38. BALL I R, REYNOLDSON T B, WARWICK T 1969 The taxonomy, habitat and distribution of the freshwater triclad Planaria torva (Platyhelminthes: Turbellaria) in Britain Journal of Zoology. 157(1): 99-123

39. SLUYS R, KAWAKATSU M 2006 Towards a phylogenetic classification of dendrocoelid freshwater planarians (Platyhelminthes): a morphological and eclectic approach. JZS 44(4): 274-284 http:// dx.doi.org/10.1111/j.1439-0469.2006.00371.x

40. SLUYS R, SOLÀ E, GRITZALIS K, VILLA-FARRÉ M, MATEOS E, RIUTORT M 2013 Integrative delineation of species of Mediterranean freshwater planarians (Platyhelminthes: Tricladida: Dugesiidae). Zoological Journal of the Linnean Society. 169(3): 523-547 http://dx.doi.org/10.1111/zoj.12077

41. KRSTANOVSKI Z 2004 Taxonomic statute of Phagocata stankovici and Phagocata ochridana (Turbellaria: Triclaadida Paludicola) established with enzyme electrophoresis. Balwois. p 1-5 